\title{
The Elimination of Hepatitis C as a Public Health Threat
}

\author{
Margaret Hellard, ${ }^{1,2,3,4}$ Sophia E. Schroeder, ${ }^{1,2}$ Alisa Pedrana, ${ }^{1,2}$ Joseph Doyle, ${ }^{1,3}$ \\ and Campbell Aitken ${ }^{1,2}$ \\ ${ }^{1}$ Disease Elimination Program, Burnet Institute, Melbourne 3004, Australia \\ ${ }^{2}$ School of Public Health and Preventive Medicine, Monash University, Melbourne 3004, Australia \\ ${ }^{3}$ Alfred Hospital, Department of Infectious Diseases, Monash University, Melbourne 3004, Australia \\ ${ }^{4}$ Doherty Institute and Melbourne School of Population and Global Health, University of Melbourne, \\ Melbourne 3000, Australia \\ Correspondence: margaret.hellard@burnet.edu.au
}

Hepatitis C virus is a global public health threat, affecting 71 million people worldwide. Increasing recognition of the impact of this epidemic and recent advances in biomedical and technical approaches to hepatitis $\mathrm{C}$ prevention and cure have provided impetus for the World Health Organization (WHO) to call for global elimination of hepatitis $\mathrm{C}$ as a public health threat by 2030 . This work reviews the feasibility of hepatitis $\mathrm{C}$ elimination and pathways to overcome existing and potential future barriers to elimination. Drawing on costeffectiveness modeling and providing examples of successful implementation efforts across the globe, we highlight the resources and strategies needed to achieve hepatitis C elimination. A timely, multipronged response is required if the $2030 \mathrm{WHO}$ elimination targets are to be achieved. Importantly, achieving hepatitis Celimination will also benefit the community well beyond 2030 .

\begin{abstract}
$A^{n}$ estimated 71 million people globally were Ainfected with the hepatitis C virus in 2017 (World Health Organization 2017a) and the World Health Organization (WHO) estimates that approximately 1.5 million new infections occur each year (World Health Organization 2018b). Since 1990, annual deaths as a result of hepatitis $\mathrm{C}$ have increased steadily, contrasting with great reductions in mortality related to other communicable diseases. Hepatitis $\mathrm{C}$ is now a leading cause of primary liver cancer (Ni et al. 2012; Heimbach et al. 2018), with an
\end{abstract}

estimated 400,000 deaths attributable to chronic hepatitis C in 2015 (World Health Organization 2018b). When combined with hepatitis B-related deaths, viral hepatitis surpasses HIV/AIDS, tuberculosis, and malaria, and is now the sixth leading cause of death worldwide (GBD 2015 Mortality and Causes of Death Collaborators 2016; Stanaway et al. 2016).

Hepatitis $\mathrm{C}$ virus is transmitted primarily through blood contact via unsterile medical and other procedures (e.g., through reuse of syringes and needles and substandard infection

Editors: Arash Grakoui, Jean-Michel Pawlotsky, and Glenn Randall

Additional Perspectives on Hepatitis C Viruses: The Story of a Scientific and Therapeutic Revolution available at www.perspectivesinmedicine.org

Copyright $\odot 2020$ Cold Spring Harbor Laboratory Press; all rights reserved; doi: 10.1101/cshperspect.a036939

Cite this article as Cold Spring Harb Perspect Med 2020;10:a036939 
M. Hellard et al.

control practices [Umar and Bilal 2012]) or sharing of contaminated injecting equipment among people who inject drugs (PWID) (Platt et al. 2017). In addition, there is evidence of sexual transmission of hepatitis $\mathrm{C}$, predominantly occurring among HIV-positive gay and bisexual men (Jin et al. 2017). Increasingly, evidence suggests that HIV-negative gay and bisexual men are also at risk of sexual acquisition of hepatitis C, particularly when sexual networks overlap (Hoornenborg et al. 2017). Although hepatitis $\mathrm{C}$ virus infection is a global epidemic, key affected populations and modes of transmission differ substantially between regions (Bruggmann et al. 2014; Liakina et al. 2015; Saraswat et al. 2015; Maaroufi et al. 2017). Depending on the country, hepatitis $\mathrm{C}$ virus infection can be concentrated among one or more defined subpopulations (e.g., PWID in Scotland [Hutchinson et al. 2006]) established in the general population, such as in Egypt (Kouyoumjian et al. 2018), or in the form of a mixed epidemic, as found in Georgia (Gvinjilia et al. 2016). Globally, hepatitis $C$ prevalence is highest among people with a history of injecting drug use, an estimated $52.3 \%$ (range $42.4 \%-62.1 \%$ ) of whom are infected (Degenhardt et al. 2017).

Chronic hepatitis $\mathrm{C}$ has major impacts on quality of life, leads to life-threatening complications, and places a substantial burden on health care systems. People living with chronic viral hepatitis experience decreased health and well-being and are subject to considerable social stigma, which can reduce workforce participation and personal financial security (Zhuang et al. 2014; World Health Organization 2017a; Younossi et al. 2017a,b, 2018a,b).

\section{ELIMINATING HEPATITIS C AS A PUBLIC HEALTH THREAT BY 2030}

Acknowledging the human impact of this epidemic, the 2014 World Health Assembly called for an intensified and expanded global hepatitis response and requested the WHO secretariat to examine the feasibility of and strategies needed for the elimination of hepatitis $\mathrm{C}$ (World Health Assembly 2014). The advent of highly effective treatment for hepatitis $\mathrm{C}$, known as direct-acting antiviral (DAA) medication, around this time led to a growing awareness that the elimination of hepatitis C may be achievable. Several mathematical models supported the view that hepatitis $\mathrm{C}$ could be eliminated as a global public health threat if the WHO targets are met (Martin et al. 2013b; Scott et al. 2017b, 2018a).

The resulting Global Health Sector Strategy on Viral Hepatitis 2016-2021 (World Health Organization 2016b) calls for the elimination of viral hepatitis as a public health threat and outlines goals, targets, frameworks for action, and critical strategic directions to achieve this goal by 2030. For hepatitis C, elimination was defined as an $80 \%$ reduction in new chronic infections and $65 \%$ reduction in mortality compared with 2015 rates (World Health Organization 2016a). WHO identified measures considered critical to achieve elimination targets, including improving blood and injecting safety coverage, increasing harm reduction coverage, and expanding access to hepatitis $\mathrm{C}$ testing and treatment (see Table 1; World Health Organization 2016b).

\section{ASSESSING THE FEASIBILITY OF HEPATITIS C ELIMINATION}

Elimination and eradication of human disease are ultimate goals of public health, the feasibility of which must be assessed on both scientific and political criteria (see Box 1; Hopkins 2013; Hellard et al. 2014). Three conditions are vital to the eradicability of any disease that affects humans: (1) an intervention is available to interrupt transmission of the disease-causing agent; (2) practical diagnostic tools with sufficient sensitivity and specificity are available to detect levels of infection that can lead to transmission; and (3) humans are essential for the life cycle of the agent, which has no other vertebrate reservoir and does not amplify in the environment (Dowdle 1998). It should be noted that the WHO targets are not calling for eradication but the elimination of hepatitis $\mathrm{C}$ as a public health threat; nonetheless, hepatitis $\mathrm{C}$ meets all three of the conditions outlined above, suggesting that elimination of the infection as a public health threat by 2030 is feasible. 
Table 1. WHO hepatitis C elimination targets

\begin{tabular}{|c|c|c|c|c|}
\hline Target area & & Baseline 2015 & 2020 target & 2030 target \\
\hline \multirow[t]{2}{*}{$\begin{array}{l}\text { Blood and injecting } \\
\text { safety coverage }\end{array}$} & $\begin{array}{l}\text { Blood safety: donations screened } \\
\text { with quality assurance }\end{array}$ & $89 \%$ & $95 \%$ & $100 \%$ \\
\hline & $\begin{array}{l}\text { Injection safety: use of engineered } \\
\text { devices }\end{array}$ & $5 \%$ & $50 \%$ & $90 \%$ \\
\hline Harm reduction & $\begin{array}{l}\text { Sterile needle/syringe sets } \\
\text { distributed per person per year } \\
\text { (for people who inject drugs) }\end{array}$ & 20 & 200 & 300 \\
\hline Testing & $\begin{array}{l}\text { Diagnosis of hepatitis C } \\
\text { (coverage \%) }\end{array}$ & $<1 \%$ & $30 \%$ & $90 \%$ \\
\hline Treatment & $\begin{array}{l}\text { Treatment of hepatitis C } \\
\quad \text { (coverage \%) }\end{array}$ & $<1 \%$ & 3 million & $\begin{array}{l}80 \% \text { eligible } \\
\text { treated }\end{array}$ \\
\hline \multirow[t]{2}{*}{ Impact } & $\begin{array}{l}\text { Incidence: new cases of viral } \\
\text { hepatitis } \mathrm{C} \text { infections }\end{array}$ & $\begin{array}{l}1.75 \text { million new } \\
\text { infections }\end{array}$ & $30 \%$ reduction & $80 \%$ reduction \\
\hline & Mortality: viral hepatitis $\mathrm{C}$ deaths & 400,000 & $10 \%$ reduction & $65 \%$ reduction \\
\hline
\end{tabular}

Scientific Feasibility of Eliminating Hepatitis C Epidemiologic Susceptibility

The elimination of a disease is more feasible when humans form the essential component of the life cycle of the disease-causing agent (Dowdle 1998). Although higher primates are susceptible to experimental infection with the hepatitis $\mathrm{C}$ virus, natural infection and ongoing transmission of the virus is limited to human populations, with no insect vector or animal reservoir (Pfaender et al. 2014). Transmission of the hepatitis $\mathrm{C}$ virus predominantly occurs in key populations or follows specific risk exposures to infected blood or contaminated products. Transmission is preventable through behavior change or improved health systems, as transmission is most common through:

1. Injecting drug use through the sharing of injection equipment;

2. The reuse or inadequate sterilization of medical equipment, especially syringes and needles in health care settings;

3. The transfusion of unscreened blood and blood products; and

4. Sexual exposure, predominantly occurring in HIV-positive gay and bisexual men.

The asymptomatic nature of hepatitis $\mathrm{C}$ infection means that many people are unaware of it unless tested. Both sensitive and specific diagnostic tools are available to detect exposure to hepatitis $\mathrm{C}$ virus (antibody tests) and evidence of ongoing infection (hepatitis $\mathrm{C}$ virus RNA or antigen tests) (World Health Organization $2017 b$ ). Fundamental to identifying people infected with hepatitis $C$ is for countries to establish appropriate testing or screening programs consistent with their epidemic (World Health Organization 2017b). Knowledge of the routes of transmission and detecting current infection provide the grounds for multipronged interventions that can interrupt onward transmission and link patients to care.

\section{Availability of Effective Interventions}

There is currently no vaccine to prevent hepatitis C, but novel DAAs have transformed the therapeutic landscape, are becoming increasingly affordable, and are now globally available (Douglass et al. 2018). These regimens can be administered for a short duration (as little as 8 weeks) and result in cure rates $>95 \%$, with fewer serious adverse events than previous interferoncontaining regimens (Doyle et al. 2013; Poordad et al. 2013; Lawitz et al. 2014; World Health Organization 2016c). With these therapeutic advances, universal access to DAA therapies is critical to attaining elimination as the potential pool of infection will decrease as treatment cov- 
M. Hellard et al.

\section{BOX 1. DISEASE ELIMINATION/ERADICATION DEFINITIONS AND REQUIREMENTS}

Elimination refers to the reduction to zero (or a very low defined target rate) of new cases in a defined geographical area as a result of deliberate efforts (Dowdle 1998). Control measures are needed to prevent re-establishment of transmission. ${ }^{\mathrm{a}}$

Eradication refers to complete and permanent worldwide reduction to zero new cases of the disease through deliberate efforts. Control measures are no longer needed.

${ }^{a}$ WHO calls for the elimination of hepatitis $\mathrm{C}$ as a public health threat-a less stringent definition that does not require new cases to be reduced to zero. Instead, WHO calls for a $90 \%$ reduction of new chronic cases by 2030 (World Health Organization 2017a).

Criteria for assessing the eradicability of a disease (Hopkins 2013)

\begin{tabular}{|c|c|}
\hline Scientific feasibility & Hepatitis C examples \\
\hline $\begin{array}{l}\text { Epidemiologic susceptibility (e.g., no nonhuman } \\
\text { reservoir, ease of spread, naturally induced } \\
\text { immunity, ease of diagnosis) }\end{array}$ & $\begin{array}{l}\text { There is no nonhuman reservoir, transmission occurs } \\
\text { through human blood contact or through } \\
\text { contaminated products that can be mitigated; } \\
\text { sensitive and specific diagnostic tests are available }\end{array}$ \\
\hline $\begin{array}{l}\text { Effective, practical intervention available (e.g., } \\
\text { vaccine, curative treatment) }\end{array}$ & $\begin{array}{l}\text { Curative treatment of high tolerability is available, } \\
\text { achieving cure rates of }>95 \%\end{array}$ \\
\hline $\begin{array}{l}\text { Showed feasibility of elimination (e.g., } \\
\text { documented elimination from an island or } \\
\text { other geographic unit) }\end{array}$ & $\begin{array}{l}\text { Micro-elimination programs such as has occurred in } \\
\text { Iceland (an island) are being demonstrated (Scott } \\
\text { et al. 2018a) }\end{array}$ \\
\hline Political commitment & Hepatitis C examples \\
\hline $\begin{array}{l}\text { Perceived burden of the disease (e.g., extent, } \\
\text { deaths, other effects; relevance to rich and poor } \\
\text { countries) }\end{array}$ & $\begin{array}{l}\text { Globally, viral hepatitis-related mortality now exceeds } \\
\text { mortality of any other chronic infectious disease } \\
\text { (GBD } 2015 \text { Mortality and Causes of Death } \\
\text { Collaborators 2016; Stanaway et al. 2016) }\end{array}$ \\
\hline Expected cost of eradication & $\begin{array}{l}\text { Modeling conducted to date suggests that global } \\
\text { implementation of hepatitis C elimination } \\
\text { strategies (2018-2030) is cost-effective and will } \\
\text { become cost-saving by } 2027 \text { (Pedrana et al. 2018) }\end{array}$ \\
\hline $\begin{array}{l}\text { Synergy of eradication efforts with other } \\
\text { interventions (e.g., potential for added benefits } \\
\text { or savings) }\end{array}$ & $\begin{array}{l}\text { Commitment to hepatitis C elimination will help } \\
\text { progress toward Sustainable Development Goal } 3 \\
\text { (Pedrana et al. 2018) }\end{array}$ \\
\hline Need for eradication rather than control & $\begin{array}{l}\text { Elimination is more cost-effective than control and } \\
\text { leads to long-term benefits to the health system } \\
\text { (Scott et al. 2017b; Pedrana et al. 2018) }\end{array}$ \\
\hline
\end{tabular}

erage continues to increase more rapidly than new infections will occur, thus providing a "treatment as prevention" benefit (Alfaleh et al. 2015; Hellard et al. 2015; Hajarizadeh et al. 2016; Chen et al. 2017). In addition, needle and syringe programs and opioid substitution therapy are effective harm reduction interventions that reduce hepatitis $\mathrm{C}$ transmissions among PWID (Aitken et al. 2017; Platt et al. 2018).

\section{Shown Feasibility of Elimination}

National and global mathematical models suggest that hepatitis $\mathrm{C}$ elimination as a public health threat is possible by 2030 (Martin et al. 2013b; Scott et al. 2017b, 2018a; Benzaken et al. 2018). Although to date no country has formally reached the WHO elimination target, let alone the target of zero new cases of hepatitis 
C infection (consistent with the formal definition of elimination), a number of countries are making strong progress (Murphy 2018) including Australia (The Boston Consulting Group 2017), Egypt (Lemoine and Cooke 2018), France (Hermetet et al. 2017; Papatheodoridis et al. 2018), Georgia (Nasrullah et al. 2017a), and Iceland (Scott et al. 2018a). Whereas country-level macro-elimination is the ultimate goal for many countries, most of the 194 countries that endorsed the WHO global health sector strategy for the elimination of hepatitis $C$ have yet to develop concrete national plans for viral hepatitis elimination (Murphy 2018). There is increasing evidence that macro-elimination will be feasible (Scott et al. 2017a,b; Cooke et al. 2019; Doyle et al. 2019), whereas micro-elimination projects serve to assess key organizational, infrastructural, and political challenges and transfer solutions to local contexts.

Micro-elimination is a pragmatic approach that shows the feasibility of elimination on a smaller, more limited scale and in a less complex and less costly fashion than a full-scale elimination program in a large populous country (Lazarus et al. 2018). This is because treatment and prevention interventions can be delivered quickly and efficiently using targeted methods. In the case of hepatitis $\mathrm{C}$, micro-elimination means implementing strategies to achieve the WHO targets in specific subpopulations (e.g., people living with HIV), settings (e.g., prisons, hospitals), cohorts (baby boomers), or geographic areas (a city or region) (Lazarus et al. 2017). These micro-elimination efforts are an important step in showing the potential impact and cost-effectiveness of elimination and are instrumental in persuading policymakers to support further expansion of such activities.

Examples in which micro-elimination has been shown to date or is close to completion include an Egyptian village (Asselah 2018), a regional prison in Australia (Bartlett et al. 2018), and the high-income island country Iceland (Scott et al. 2018a), described in more detail below.

Approximately 1100 Icelanders were chronically infected with hepatitis C in 2016, most with a history of injecting drug use (Olafsson et al. 2018). Given the relatively small numbers requiring treatment, Iceland is an example of a geographic area where the implementation of a nationwide program to tackle hepatitis C-related morbidity and reduce domestic incidence of hepatitis $\mathrm{C}$ in the population by $80 \%$ before 2030 means that micro-elimination could be effective and indeed is well underway. In 2016, Iceland launched a nationwide hepatitis $\mathrm{C}$ elimination program offering DAA therapy to every infected patient. Aiming to treat most patients within the first two years of the program, the initial focus was on reaching PWID, prisoners, and those at highest risk of liver cirrhosis. Rapid point-ofcare (POC) testing for hepatitis C and HIV facilitates access to hepatitis diagnostics and treatment for hard-to-reach populations. To further stimulate uptake of hepatitis $\mathrm{C}$ care, testing and treatment activities are complemented by tailored public awareness campaigns in the mass media. This multipronged approach, combining improved harm-reduction strategies, scale-up of prevention, and testing and early treatment of hepatitis $\mathrm{C}$ in hospital and community settings puts Iceland on track to achieve the WHO goal of elimination as early as 2020 (Scott et al. 2018a).

\section{Political Commitment}

Although the scientific feasibility of viral hepatitis elimination can be shown, the success of disease elimination efforts is largely dependent on the level and consistency of societal and political commitment (Dowdle 1998). Major investments are needed to reach this ambitious goal, as elimination programs are distinct from ongoing health or disease-control programs in their urgency and requirements for targeted surveillance, rapid response capability, high standards of performance, and a dedicated focal point at the national level (Dowdle 1998). Investment cases and mathematical modeling can be used to show the cost-effectiveness and affordability of elimination strategies (Hecht et al. 2018; Pedrana et al. 2018), but sustained political will is needed for their implementation. A few key factors influence this cost-benefit analysis, as discussed below. 
M. Hellard et al.

\section{Burden of the Disease}

Globally, it is estimated that $<20 \%$ of people living with chronic viral hepatitis are aware of their status, although there is considerable variation within and between regions (World Health Organization 2017a). For example, by 2016, only $5 \%$ of people living with chronic hepatitis $\mathrm{C}$ in the WHO African region had been diagnosed (World Health Organization Regional Office for Africa 2017), compared with an estimated $36.7 \%$ of people living with chronic hepatitis $\mathrm{C}$ in Europe (European Union HCV Collaborators 2017), 36\% in the Americas, $21 \%$ in the Western Pacific Region, $17 \%$ in the Eastern Mediterranean Region, and 9\% in Southeast Asia (World Hepatitis Alliance 2018). Using Europe as an example of regional disparities, the proportion of diagnosed hepatitis C cases in Malta (91.7\%), Sweden (84.6\%), and Finland (77.4\%) stand in stark contrast with low diagnosis rates in Cyprus $(10 \%)$ and Slovakia (9.4\%), among others (European Union HCV Collaborators 2017). Lack of public awareness and knowledge among health care practitioners contribute to low diagnosis rates and perceived disease burden, which in turn lead to insufficient demand for treatment access and advocacy for innovation (World Hepatitis Alliance 2018). A survey of eight countries conducted for the World Innovation Summit for Health (WISH) in 2018 by YouGov, an international internet-based market research and data analytics organization, found that knowledge about the effectiveness of prevention and treatment was also low, with $>40 \%$ of respondents unaware that hepatitis $\mathrm{C}$ can be cured (Pedrana et al. 2018; YouGov 2018).

Nevertheless, compelling data highlight the considerable morbidity and mortality associated with hepatitis $C$ and the costs of managing this chronic infection (GBD 2015 Mortality and Causes of Death Collaborators 2016; Stanaway et al. 2016). The inclusion of viral hepatitis as a focus of the Agenda for Sustainable Development (Target 3.3; United Nations 2015) and the global endorsement of the hepatitis $\mathrm{C}$ elimination goal are markers of growing awareness. In light of more accurate perceptions of the public health impact of hepatitis $C$, the number of countries with national hepatitis $\mathrm{C}$ policies and plans is increasing steadily, providing frameworks for action and resource mobilization (World Health Organization 2017a; World Hepatitis Alliance 2018) (see Box 2).

\section{Expected Cost of Elimination}

The resources needed and costs associated with national elimination programs are predominantly country- and context-specific. Mathematical modeling can help estimate the overall costs and affordability of different strategies and inform policymaking to maximize benefits of investments (or highlight the costs of inaction) (Hecht et al. 2018).

Recent modeling studies conducted in Egypt (Elsisi et al. 2017), France (Cousien et al. 2018), South Africa (Fraser et al. 2016), and the United Kingdom (Ward et al. 2017) have found DAA treatment to be cost-effective even when the cost of treatment is relatively high (Cipriano and Goldhaber-Fiebert 2018), except in settings in which chronic prevalence and reinfection risk is high (Martin et al. 2016). With decreasing treatment costs over the past few years, treatment is increasingly cost-effective. The WISH 2018 research forum on viral hepatitis built a global investment case for viral hepatitis elimination (World Innovation Summit for Health 2018). Modeling conducted for that report showed that reducing hepatitis $\mathrm{C}$ virus prevalence and incidence through treatment as prevention requires substantial financial investments but is cost-effective and becomes costsaving by 2027 (Pedrana et al. 2018). The report estimated that the total cost of global hepatitis $C$ elimination would reach $\$ 51$ billion between 2018 and 2030, with minimal ongoing cost after 2030. In comparison, the current expenditure on HIV, tuberculosis, and malaria strategies will add up to $\$ 343.2$ billion over the same time period, while diminishing those epidemics only marginally. Therefore, although eliminating hepatitis $\mathrm{C}$ requires significant financial investments in the short term, the substantial long-term benefits and economic savings of elimination justify political and popular support for such investments (Pedrana et al. 2018). 


\section{BOX 2. EGYPT - POLITICAL COMMITMENT ATTRIBUTABLE TO A HIGH BURDEN OF DISEASE}

Egypt is a lower middle-income country with a very high burden of hepatitis C infection and disease that has shown strong political commitment to hepatitis C elimination. In 2015, it was estimated that 3.8 million (7\%) of Egyptians aged 18-59 were living with chronic hepatitis C (Kandeel et al. 2017). The high endemicity of hepatitis $C$ in Egypt is mostly attributable to transmission through injections to treat schistosomiasis between the 1950s and 1980s (Strickland 2006). The large pool of people living with hepatitis $\mathrm{C}$ combined with continued unsafe medical practices in the official and nonofficial health systems have contributed to ongoing transmission. In 2016, an estimated 150,000 Egyptians were newly infected with the virus (The World Bank 2017). In spite of these staggering figures, Egypt is working to achieve the $\mathrm{WHO}$ elimination targets with the country providing free and universal access to effective hepatitis $C$ treatment. The government conducted effective price negotiations and removed patent barriers, allowing the local production of DAAs for hepatitis C treatment (Assefa et al. 2017; Ayoub and Abu-Raddad 2017). With affordable drugs secured, the country is now undertaking a major, concerted, nationwide screening and treatment effort (Alcorn 2018; Elsharkawy et al. 2018). By the end of 2017, >1200 communities were screened and more than 1.6 million Egyptians received treatment (The World Bank 2017; Lemoine and Cooke 2018). Between October 2018 and September 2019, the government aimed to screen all Egyptian adults not tested or treated before-targeting 52 million individuals-and provide treatment to those identified with hepatitis $\mathrm{C}$ virus infection. To maximize efficiencies, screening also included assessments for hypertension, diabetes, and obesity. Although there is still much work to be done, and caution is required until the final numbers who are tested and treated become available, this unprecedented approach can serve as a model for other nations with similar disease burden and resource constraints (Elsharkawy et al. 2018).

\section{Synergy between Elimination Efforts and Other Interventions}

Strategies exist to reduce the cost of elimination. Combining harm reduction strategies such as needle and syringe programs and opioid substitution therapy with antiviral treatment is relatively inexpensive and critical for achieving substantial reductions in hepatitis $\mathrm{C}$ prevalence and incidence (Kwon et al. 2012; Martin et al. 2013a; Palmateer et al. 2014; Aitken et al. 2017; Platt et al. 2018). Modeling by Scott and colleagues suggests that such interventions are cost-saving even if they affect the epidemic marginally (Scott et al. 2017a). Many of the hepatitis C interventions can be piggybacked onto existing HIV services to reduce cost, as countries such as Brazil (Mesquita et al. 2016) and Georgia (Gvinjilia et al. 2016) have done. Applying a public health approach and embedding hepatitis $C$ strategies into the Agenda for Sustainable Development and Universal Health Coverage leads to multisectoral benefits beyond the elimination of a leading cause of global deaths (Pedrana et al. 2018) (see Box 3). Specific action items include:
1. Provision of adequate coverage of harm reduction (World Health Organization 2016b);

2. Implementation of effective strategies to increase access to testing as the necessary entry point to treatment;

3. Development and implementation of flexible, community-based models of care that increase opportunities for testing and treatment across low-, middle-, and high-prevalence settings;

4. Improvement of treatment access for all affected people by targeting financial, logistical, and social barriers (e.g., stigmatization of the disease); and

5. Reduction of costs of medications to facilitate universal access.

\section{Need for Elimination Rather than Control}

Despite the substantial short-term investments needed to achieve elimination, in the longer 
M. Hellard et al.

\section{BOX 3. SCOTLAND - INVESTMENT INFORMED BY EVIDENCE}

In Scotland, social and political recognition of the scale of hepatitis $\mathrm{C}$ as a public health problem galvanized policymakers into action. Advocates used political pressure and scientific evidence to raise awareness of the human impact of hepatitis $C$ and its links to inequalities. This generated the necessary political consensus to support significant funding and evidence-based policy initiatives. Innovative strategies such as the introduction of dried blood spot sampling in community drug services made the model of viral hepatitis care more acceptable to affected communities and helped overcome barriers to testing (McLeod et al. 2014). Adopting a project management approach ensured achievable goal-setting and controlled ongoing cost. Investment in a robust monitoring and surveillance system, combined with ambitious targets, facilitated progress and yielded evidence of the investment's immediate impact. Scotland's Hepatitis C Action Plan has led to a significant decline in hepatitis C, a 30\% increase in new diagnoses, sharp increases in people being treated and cured of hepatitis C, and an overall decrease in the population prevalence of chronic hepatitis C (Wylie et al. 2014; Hutchinson et al. 2015). The plan has shown that evidence-based national hepatitis C strategies, based on scientific feasibility and supported by significant political commitment, can reduce the financial and societal burden of the epidemic (Global Commission on Drug Policy (GCDP) 2013).

term, elimination provides a bigger return on investment than any strategy that diminishes the epidemic marginally. Alongside substantial reductions in transmission, morbidity, and mortality, investing in hepatitis $\mathrm{C}$ elimination is estimated to become cost-saving as early as 2027 (Pedrana et al. 2018). Early financial commitment is required to maximize the benefits of investing in hepatitis $\mathrm{C}$ elimination and prevent ongoing costs associated with disease control, namely hepatitis $\mathrm{C}$ screening, treatment, and management of disease progression and longterm sequelae (Pedrana et al. 2018). In addition, financial commitment is needed to support the development of diagnostics and a vaccine. Barriers to rapid testing (development, commercialization, regulation, subsidy) and vaccination (development, market) are preventing the quick and effective development of these tools in our elimination arsenal.

\section{STRATEGIC DIRECTIONS FOR IMPLEMENTATION}

Despite global agreement to aim for hepatitis C elimination by 2030, having the biomedical tools available to test and treat infection, and effective mechanisms to reduce the risk of ongoing transmission, implementation has been slow and faces many challenges (Popping et al.
2018). Few countries have commenced concerted elimination programs. Even in settings where unrestricted and unlimited hepatitis $C$ treatment scale-up is available, further policy and health system interventions are required to improve the cascade of hepatitis $\mathrm{C}$ care and achieve WHO elimination targets (Scott et al. 2017a). To date, only 12 countries are considered to be on track to achieve the 2030 elimination targets (Murphy 2018). Key challenges include low levels of awareness overall, a lack of prioritization among policymakers, poor infrastructure, inadequate data and weak surveillance systems, low levels of investments in health, and lack of dedicated funding for viral hepatitis (see Box 4; Fitzsimons 2015; Viral Hepatitis Prevention Board 2016).

With the aim of supporting all countries in their efforts to eliminate hepatitis $\mathrm{C}$ to achieve global elimination, the Global Health Sector Strategy for Viral Hepatitis 2016-2021 outlines strategic directions for implementation to improve the proportion of people engaged with and retained in the continuum of hepatitis services (see Fig. 1). To maximize efficiencies and equity outcomes, countries should deliver these interventions using a public health approach and adopt universal health coverage as an organizing framework (World Health Organization 2016b). 


\section{BOX 4. FRANCE-TAKING A LONG-TERM STRATEGIC APPROACH TO ADDRESSING BARRIERS TO HEPATITIS C ELIMINATION}

France is an example of a country that has long invested in the control of hepatitis $C$ and managed to address these challenges effectively. As early as the 1990s, France made the prevention and control of hepatitis $C$ virus infection a public health priority. The country conducted a series of epidemiological surveys in 1994 to inform the development of the world's first national plan for viral hepatitis prevention and control. In 1999, health authorities launched France's first hepatitis C program, including a public health response for primary prevention, the promotion of hepatitis $C$ testing, improved access to treatment (Delile et al. 2018), and research (Brody 2011; Hermetet et al. 2017). Repeated TV and radio awareness campaigns helped to substantially increase hepatitis $\mathrm{C}$ testing numbers (The Boston Consulting Group 2017) and resulted in diagnosis rates of $>74 \%$ (European Union HCV Collaborators 2017). France was one of the first countries to announce a commitment to hepatitis $C$ elimination in 2016, including plans for universal access to DAAs. Strong government commitment and civil society support, well-defined governance models and monitoring plans, and a targeted, data-driven approach to integrated hepatitis $C$ testing and treatment within systems and networks commonly used by high-prevalence populations have facilitated high treatment rates and make France one of the 12 countries on track to achieve hepatitis C elimination by 2030 (Murphy 2018).

\section{Information for Focused Action}

There is a need to understand the hepatitis $C$ epidemic and response as a basis for advocacy, political commitment, national planning, resource mobilization and allocation, implementation, and program improvement (World Health Organization 2016a).

In many countries, competing health priorities, tight health budgets, and opportunity costs have meant that hepatitis $\mathrm{C}$ has long been ignored as a public health concern. A lack of awareness and prioritization among policymakers is often caused by inadequate data and weak surveillance systems, compounded by a lack of awareness among the general population and at-risk populations who fail to demand action by their governments (World Health Organization 2016b). The true national burden of hepatitis $\mathrm{C}$ is commonly underestimated, including its impact on health care costs, workforce participation, and productivity.

For an effective hepatitis response, accurate national and subnational data are imperative because they allow the establishment of a baseline from which to monitor progress (Popping et al. 2018). Hepatitis surveillance programs must be strengthened to identify where gaps in the hepatitis $\mathrm{C}$ care cascade persist and which subpopulations remain underserved. Accurate estimates for country-specific contexts facilitate mathematical modeling of the cost-effectiveness and affordability of a variety of interventions for maximum reach, and guide pathways to elimination (Scott et al. 2017a,b; Hecht et al. 2018). Where needed, governments should seek assistance from technical advisory groups to establish national hepatitis $\mathrm{C}$ action plans (Hecht et al. 2018).

International organizations and agencies can raise awareness among the community and policymakers through regularly reporting on progress toward 2030 elimination targets at the global, regional, and country levels. Hepatitis $\mathrm{C}$ advocates can use these data and progress reports to demand further national and global donor investment.

\section{Interventions for Impact}

The strategic direction "interventions for impact" (see Fig. 1) focuses on essential interventions to enhance hepatitis $C$ virus prevention and treatment of existing infections. Prompt and accurate diagnosis of infection is a foundation of infectious disease control and a prerequisite to disease elimination. In 2015, only 14 million individuals living with hepatitis $\mathrm{C}$ (20\% of those infected) were aware of their infection and, of these, only a quarter had 
M. Hellard et al.

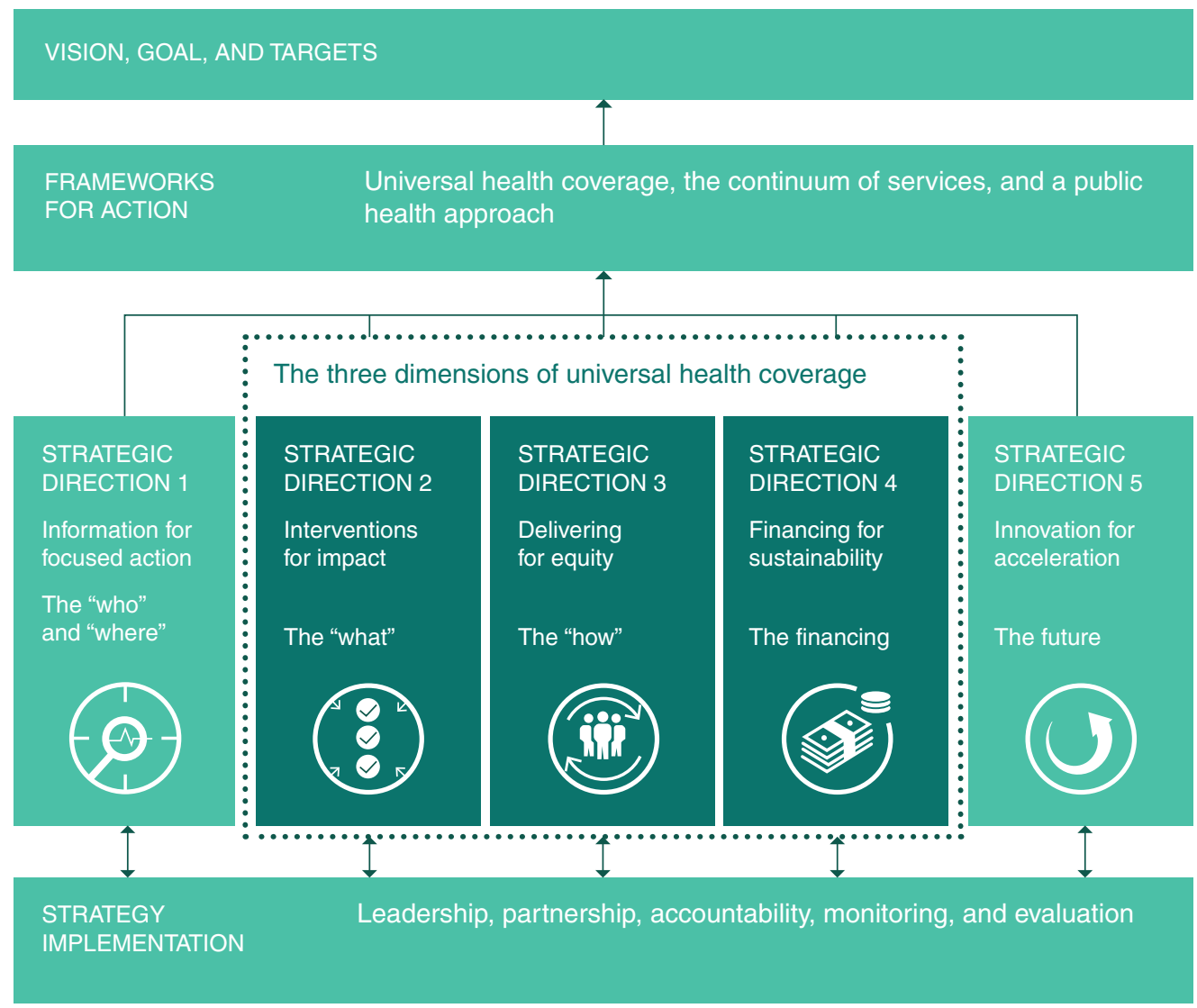

Figure 1. The five strategic directions of the Global Health Sector Strategy on Viral Hepatitis, 2016-2021. (Data in figure adapted from World Health Organization 2016b.)

received treatment (World Health Organization 2017a).

Increasing the proportion of diagnosed hepatitis $C$ patients is a critical first step to optimizing the hepatitis $\mathrm{C}$ care cascade as a pathway to treatment and cure, including treatment of reinfection. To achieve the $80 \%$ reduction in incidence by 2030, an increase in hepatitis $C$ virus RNA testing rates is required, either through biomedical/technological advancements (e.g., POC RNA tests) or increased engagement in care for those with hepatitis $\mathrm{C}$ antibodies detected (Scott et al. 2017a).

Modeling based on accurate data can assist with estimating the necessary testing frequencies to maximize population-level benefits of treatment among key population groups, as they are likely to depend on prevalence estimates and testing coverage. A recent modeling study took these parameters into account and found that in settings of low hepatitis $\mathrm{C}$ prevalence among PWID (<25\%), two-yearly antibody testing is sufficient to achieve elimination by 2027-2030; increasing testing frequency would reduce the time to elimination further. In comparison, the model found that in high-prevalence settings (75\% of PWID infected) even three-monthly hepatitis $\mathrm{C}$ virus RNA/cAg testing and $100 \%$ retention in care is insufficient to achieve the WHO 2030 targets (Scott et al. 2018b). The implications of this are that achieving the 2030 targets requires improved coverage of harm reduction services (Martin et al. 2013a), such as needle and syringe programs and opioid substitution therapy, which have been shown to reduce the risk of hepatitis $\mathrm{C}$ virus infection 
(Turner et al. 2011; Aitken et al. 2017; Platt et al. 2018).

Multiple complex systemic and social factors contribute to low hepatitis $\mathrm{C}$ testing rates (Zhou et al. 2016; Scott et al. 2017a), including low awareness among affected populations, poor infrastructure for providing hepatitis $\mathrm{C}$ assessment (Grebely et al. 2013) and misconceptions about the treatability of hepatitis $\mathrm{C}$ in those with ongoing substance use (Lambert et al. 2011). The substantial stigma associated with hepatitis $\mathrm{C}$ virus infection further impedes access to hepatitis C care (Harris and Rhodes 2013), but innovative strategies can address these barriers. For example, introducing rapid POC antibody testing and POC RNA testing, or replacing hepatitis $\mathrm{C}$ antibody testing with POC RNA testing, is crucial to mitigate the scarcity of resources and infrastructure limitations in low- and middle-income countries (Ford et al. 2015; Grebely et al. 2017). At the same time, it needs to be acknowledged that some countries may already have the laboratory infrastructure to support RNA and antigen testing, with POC adding a potential extra cost. In such settings, simplification of the system, rather than POC testing, may be the solution. Further initiatives in these settings should prioritize (1) increased awareness and testing; (2) simplification of service delivery; (3) integration of services; (4) peer support; (5) affordable access to DAAs; (6) standardization of treatment; (7) treatment within a framework of comprehensive prevention; (8) tracking progress; (9) dedicated funding; and (10) enabling policies (Ford et al. 2015). In Scotland, for example, the introduction of dried blood spot sampling in community drug services resulted in a substantial increase in the proportion of patients tested and linked to care (McLeod et al. 2014; Hutchinson et al. 2015).

\section{Delivering for Equity}

Strategic direction "delivering for equity" aims to ensure that people in need of services enjoy equitable service access, to maximize impact and guarantee high quality. In the absence of an effective vaccine, DAA treatment as prevention marks the cornerstone of hepatitis C elim- ination (Hajarizadeh et al. 2016; Ayoub and Abu-Raddad 2017; Lazarus et al. 2017). Current guidelines for hepatitis $\mathrm{C}$ care recommend considering everyone for treatment (AASLD-IDSA HCV Guidance Panel 2018; European Association for the Study of the Liver 2018; World Health Organization 2018a). The capacity of countries to provide universal treatment access is often dependent on their ability to negotiate discounted drug prices with patent holders (World Health Organization 2017a; Douglass et al. 2018). Although the prices of DAAs have declined since their introduction in 2013, they vary considerably by country, from less than U.S. $\$ 100$ per treatment course to approximately U.S. \$40,000 (Andrieux-Meyer et al. 2015; Iyengar et al. 2016; Rosenthal and Graham 2016; Ghinea et al. 2017).

Voluntary licensing agreements and ability to produce generics have enabled significantly reduced drug prices in many low- and middleincome countries (Douglass et al. 2018) but some middle-income countries with high prevalence have not benefited from these agreements (Andrieux-Meyer et al. 2015; Douglass et al. 2018). Countries should develop and implement national hepatitis plans that include strategies to reduce prices of prevention, diagnostics, and medicines and encourage investment in development of low-cost medicines, diagnostics, and prevention products (Pedrana et al. 2018). International health organizations and agencies can also promote access to affordable medications, for example, through price regulations, supporting generic competition, using flexibilities in the Trade-Related Aspects of Intellectual Property Rights (TRIPS) agreements, and patent challenges (Douglass et al. 2018).

Adequate data are needed to inform models of the most cost-effective approaches to treatment rollout in resource-limited settings where there are competing health priorities. Whereas universal access should be the focus, particularly with the decreasing cost of therapy (Martin et al. 2016), modeling indicates that the substantial prevention benefits of treatment mean that treating PWID is the most cost-effective prioritization strategy in contexts with low and moderate hepatitis $\mathrm{C}$ prevalence $(<60 \%$ PWID 
M. Hellard et al.

chronically infected), whereas in higher-prevalence settings, treating former PWID or people with moderate fibrosis and delaying treatment among current users is most cost-effective (Scott et al. 2016, 2018b).

\section{Sustainable Financing}

Strategic direction 4, "financing for sustainability," addresses the substantial costs associated with developing and implementing new strategies to invigorate national responses to viral hepatitis, with most countries lacking dedicated hepatitis budgets or programs, and limited funding being available at an international level. Although the private sector (e.g., pharmaceutical companies) and international organizations have an important role to play in global elimination efforts, most funding will have to be mobilized from public, domestic sources to ensure sustained improvements to and uptake of hepatitis $C$ services as part of a broader effort to increase investments in health (Fitzsimons et al. 2016) and achieving universal health coverage (United Nations 2015). Making use of existing structures (e.g., HIV or tuberculosis programs) and a workforce already trained in health can save costs and generate efficiencies, as well as maximizing access to services and reducing missed opportunities to serve the populations' varied health needs (Pedrana et al. 2018). Multiple countries have been able to make treatment accessible to the broader population by successfully negotiating with patent holders (e.g., Australia), making use of patent licenses either available directly from the patent owner or those held by the Medicines Patent Pool (e.g., Rwanda [Medicines Patent Pool 2015]), or using TRIPS flexibilities to circumvent patent barriers to accessing lower-priced generic DAAs (e.g., Malaysia [Douglass et al. 2018]).

\section{Innovation for Acceleration}

The fifth strategic direction encourages countries to identify where innovation is required to shift the trajectory of the hepatitis response for the responses to be accelerated and for the elimination targets to be met. Countries such as Georgia and Australia, which committed early to achieve elimination and provide unrestricted treatment access, managed to achieve rapid treatment uptake during the first 20 months of DAA availability (Nasrullah et al. 2017b; Doyle et al. 2019). Since then, these countries have experienced a significant drop-off in patients undergoing screening and confirmatory testing and considerable decline in treatment numbers (The Kirby Institute 2017). This underscores that universal availability of DAA treatment alone is not enough to improve access to diagnosis and retention in care; further policy and health system interventions are needed that facilitate treatment access for key populations (Scott et al. 2017a). Implementing more acceptable models of care can help overcome ongoing policy, structural, and program challenges to treatment scale-up (Scott et al. 2017a; The Kirby Institute 2017).

At present, substantial health system limitations result in losses to follow-up at each of the steps of the care cascade. To achieve hepatitis $\mathrm{C}$ cure, in most countries infected individuals currently must undergo (1) a blood test to detect hepatitis $\mathrm{C}$ antibodies (which could be present because of acute, chronic, or resolved infection); (2) a test to detect hepatitis C RNA (to distinguish current infection from previous infections); (3) a genotype test to determine the correct treatment protocol; (4) an assessment of liver fibrosis through either an aspartate aminotransferase-to-platelet ratio index (APRI), other serum fibrosis biomarkers, or transient elastography (e.g., FibroScan [Echosens], HepaScore) to determine the treatment protocol and the need for post-treatment follow-up; and in most settings (5) a further consultation to commence treatment (Yehia et al. 2014; Scott et al. 2017a). Biomedical or technological advancements and changes to hepatitis $\mathrm{C}$ care guidelines present opportunities to reduce loss to follow-up simply by reducing the number of contacts with health services (and blood tests) to be diagnosed, treated, and cured. This saves money for both the individual and the health system.

Streamlined clinical pathways and simplified clinical guidelines provide further modalities to reach the rapid increase of treatment coverage needed to capitalize on treatment 
availability (Pedrana et al. 2018). Limiting prescribing to specialists is a public health system constraint that impedes treatment access in most countries. Shifting treatment delivery from tertiary hospitals and specialists to community-based services already providing health services to key risk populations can help overcome limitations in health system capacity (Wade et al. 2015). Further optimization of the hepatitis $\mathrm{C}$ care cascade can be achieved by sending clinical reminders to prompt testing; education and on-site testing by health care staff at facilities serving high-risk populations (such as needle and syringe programs or opioid substitution therapy prescribers/dispensers); nurseled education sessions on treatment; guided referral into specialist services; and coordinated mental health, substance use, and hepatitis C treatment services (Zhou et al. 2016).

\section{CONCLUSION}

Elimination and eradication of human disease are ultimate goals of public health. In the case of hepatitis $\mathrm{C}$, recent biomedical and technological advances have improved the feasibility of elimination, and widespread community empowerment, political commitment, and increasing national investment make the disease a strong candidate for elimination (Hellard et al. 2014). There has been considerable progress in the three years since the 194 WHO member states endorsed the global health sector strategy to eliminate hepatitis $\mathrm{C}$ as a public health threat by 2030 . Yet only 12 countries are currently on track to achieve elimination and considerable effort is required if the elimination targets are to become reality.

Applying a public health approach to hepatitis C elimination means ensuring the equitable distribution of hepatitis $\mathrm{C}$ prevention and treatment initiatives that focus on reaching even the most marginalized and remote communities. DAA prices in some countries continue to present a cost barrier that must be overcome to achieve the treatment scale-up necessary to reach elimination targets. In addition to scaling up treatment, substantial improvements to the cascade of care are necessary, as hepatitis $\mathrm{C}$ trans- mission will continue to occur among undiagnosed PWID and in health-care settings with suboptimal infection control. Hepatitis C awareness must increase among affected communities, policymakers, and the general public to generate sufficient demand for testing and treatment.

Eliminating hepatitis $\mathrm{C}$ as a global public health threat is possible within one or two decades if we implement a concerted multipronged response. Such an approach provides multisectoral benefits while helping countries progress on the Agenda for Sustainable Development.

\section{REFERENCES}

AASLD-IDSA HCV Guidance Panel. 2018. Hepatitis C guidance 2018 update: AASLD-IDSA recommendations for testing, managing, and treating hepatitis $\mathrm{C}$ virus infection. Clin Infect Dis 67: 1477-1492. doi:10.1093/cid/ ciy585

Aitken CK, Agius PA, Higgs PG, Stoové MA, Bowden DS, Dietze PM. 2017. The effects of needle-sharing and opioid substitution therapy on incidence of hepatitis $\mathrm{C}$ virus infection and reinfection in people who inject drugs. Epidemiol Infect 145: 796-801. doi:10.1017/ S0950268816002892

Alcorn T. 2018. Why Egypt is at the forefront of hepatitis C treatment. The Atlantic, May 29, 2018.

Alfaleh FZ, Nugrahini N, Matičič M, Tolmane I, Alzaabi M, Hajarizadeh B, Valantinas J, Kim DY, Hunyady B, Abaalkhail F, et al. 2015. Strategies to manage hepatitis $C$ virus infection disease burden-volume 3. J Viral Hepat 22 (Suppl 4): 42-65. doi:10.1111/jvh.12474

Andrieux-Meyer I, Cohn J, de Araújo ES, Hamid SS. 2015. Disparity in market prices for hepatitis $\mathrm{C}$ virus directacting drugs. Lancet Glob Health 3: e676-e677. doi:10 .1016/S2214-109X(15)00156-4

Assefa Y, Hill PS, Ulikpan A, Williams OD. 2017. Access to medicines and hepatitis $C$ in Africa: can tiered pricing and voluntary licencing assure universal access, health equity and fairness? Global Health 13: 73. doi:10.1186/s12992017-0297-6

Asselah T. 2018. A village without hepatitis C in Egypt: will micro-elimination lead to macro-elimination? Lancet Gastroenterol Hepatol 3: 734-736. doi:10.1016/S24681253(18)30178-X

Ayoub HH, Abu-Raddad LJ. 2017. Impact of treatment on hepatitis $\mathrm{C}$ virus transmission and incidence in Egypt: a case for treatment as prevention. J Viral Hepat 24: 486495. doi:10.1111/jvh.12671

Bartlett SR, Fox P, Cabatingan H, Jaros A, Gorton C, Lewis R, Priscott E, Dore GJ, Russell DN. 2018. Demonstration of near-elimination of hepatitis $C$ virus among a prison population: the lotus glen correctional centre hepatitis $\mathrm{C}$ treatment project. Clin Infect Dis 67: 460-463. doi:10 $.1093 / \mathrm{cid} / \mathrm{ciy} 210$

Benzaken A, Catapan E, Girade R, Razavi H, Schmelzer J, Pessoa M, Ferraz ML, Ferreira P, Martinelli A, Correa 
M. Hellard et al.

MCM. 2018. Hepatitis C elimination by 2030 is feasible in Brazil: a mathematical modelling approach. J Hepatol 68: S193. doi:10.1016/S0168-8278(18)30598-1

Brody H. 2011. Hepatitis C. Nature 474: S1. doi:10.1038/ 474S1a

Bruggmann P, Berg T, Øvrehus AL, Moreno C, Brandão Mello CE, Roudot-Thoraval F, Marinho RT, Sherman M, Ryder SD, Sperl J, et al. 2014. Historical epidemiology of hepatitis C virus (HCV) in selected countries. J Viral Hepat 21(Suppl 1): 5-33. doi:10.1111/jvh.12247

Chen DS, Hamoudi W, Mustapha B, Layden J, Nersesov A Reic T, Garcia V, Rios C, Mateva L, Njoya O, et al. 2017. Strategies to manage hepatitis $\mathrm{C}$ virus infection disease burden-volume 4. J Viral Hepat 24(Suppl 2): 44-63. doi:10.1111/jvh.12759

Cipriano LE, Goldhaber-Fiebert JD. 2018. Population health and cost-effectiveness implications of a "treat all" recommendation for HCV: a review of the model-based evidence. MDM Policy Pract 3: 2381468318776634. doi:10 $.1177 / 2381468318776634$

Cooke GS, Andrieux-Meyer I, Applegate TL, Atun R, Burry JR, Cheinquer H, Dusheiko G, Feld JJ, Gore C, Griswold MG, et al. 2019. Accelerating the elimination of viral hepatitis: a Lancet Gastroenterology \& Hepatology Commission. Lancet Gastroenterol Hepatol 4: 135-184. doi:10 $.1016 /$ S2468-1253(18)30270-X

Cousien A, Tran VC, Deuffic-Burban S, Jauffret-Roustide M, Mabileau G, Dhersin JS, Yazdanpanah Y. 2018. Effectiveness and cost-effectiveness of interventions targeting harm reduction and chronic hepatitis $\mathrm{C}$ cascade of care in people who inject drugs: the case of France. J Viral Hepat 25: 1197-1207. doi:10.1111/jvh.12919

Degenhardt L, Peacock A, Colledge S, Leung J, Grebely J, Vickerman P, Stone J, Cunningham EB, Trickey A, Dum chev K, et al. 2017. Global prevalence of injecting drug use and sociodemographic characteristics and prevalence of HIV, HBV, and HCV in people who inject drugs: multistage systematic review. Lancet Glob Health 5: e1192-e1207. doi:10.1016/S2214-109X(17)30375-3

Delile JM, de Ledinghen V, Jauffret-Roustide M, Roux P, Reiller B, Foucher J, Dhumeaux D. 2018. Hepatitis C virus prevention and care for drug injectors: the French approach. Hepatol Med Policy 3: 7. doi:10.1186/s41124018-0033-8

Douglass CH, Pedrana A, Lazarus JV, 't Hoen EFM, Hammad R, Leite RB, Hill A, Hellard M. 2018. Pathways to ensure universal and affordable access to hepatitis $C$ treatment. BMC Med 16: 175. doi:10.1186/s12916-018-1162-z

Dowdle WR. 1998. The principles of disease elimination and eradication. Bull World Health Organ 76(Suppl 2): 22-25.

Doyle JS, Aspinall E, Liew D, Thompson AJ, Hellard ME. 2013. Current and emerging antiviral treatments for hepatitis C infection. Br J Clin Pharmacol 75: 931-943. doi:10 $.1111 /$ j.1365-2125.2012.04419.x

Doyle JS, Scott N, Sacks-Davis R, Pedrana AE, Thompson AJ, Hellard ME. 2019. Treatment access is only the first step to hepatitis $C$ elimination: experience of universal anti-viral treatment access in Australia. Aliment Pharmacol Ther 49: 1223-1229. doi:10.1111/apt.15210

Elsharkawy A, El-Raziky M, El-Akel W, El-Saeed K, Eletreby R, Hassany M, El-Sayed MH, Kabil K, Ismail SA, El-Serafy $\mathrm{M}$, et al. 2018. Planning and prioritizing direct-acting antivirals treatment for HCV patients in countries with limited resources: lessons from the Egyptian experience. J Hepatol 68: 691-698. doi:10.1016/j.jhep.2017.11.034

Elsisi GH, Aburawash A, Waked E. 2017. Cost-effectiveness analysis of new HCV treatments in Egyptian cirrhotic and non-cirrhotic patients: a societal perspective. Value Health Reg Issues 13: 7-15. doi:10.1016/j.vhri.2017.03 .012

European Association for the Study of the Liver. 2018. EASL recommendations on treatment of hepatitis C 2018. J Hepatol 69: 461-511. doi:10.1016/j.jhep.2018.03.026

European Union HCV Collaborators. 2017. Hepatitis C virus prevalence and level of intervention required to achieve the WHO targets for elimination in the European Union by 2030: a modelling study. Lancet Gastroenterol Hepatol 2: 325-336. doi:10.1016/S2468-1253(17)30045-6

Fitzsimons D. 2015. A viral hepatitis free future: how to make it feasible and affordable. In Meeting of the Viral Hepatitis Prevention Board, London, June 5-6.

Ford N, Wiktor S, Kaplan K, Andrieux-Meyer I, Hill A, Radhakrishnan P, Londeix P, Forette C, Momenghalibaf A, Verster A, et al. 2015. Ten priorities for expanding access to HCV treatment for people who inject drugs in low- and middle-income countries. Int J Drug Policy 26: 1088-1093. doi:10.1016/j.drugpo.2015.05.004

Fraser I, Burger J, Lubbe M, Dranitsaris G, Sonderup M, Stander T. 2016. Cost-effectiveness modelling of sofosbuvir-containing regimens for chronic genotype 5 hepatitis $\mathrm{C}$ virus infection in South Africa. Pharmacoeconomics 34: 403-417. doi:10.1007/s40273-015-0356-x

GBD 2015 Mortality and Causes of Death Collaborators. 2016. Global, regional, and national life expectancy, allcause mortality, and cause-specific mortality for 249 causes of death, 1980-2015: a systematic analysis for the Global Burden of Disease Study 2015. Lancet 388: 14591544. doi:10.1016/S0140-6736(16)31012-1

Ghinea N, Lipworth W, Day R, Hill A, Dore GJ, Danta M. 2017. Importation of generic hepatitis $C$ therapies: bridging the gap between price and access in high-income countries. Lancet 389: 1268-1272. doi:10.1016/S01406736(16)32051-7

Global Commission on Drug Policy (GCDP). 2013. The negative impact of the war on drugs on public health: the hidden hepatitis $C$ epidemic. GCDP, Geneva.

Grebely J, Oser M, Taylor LE, Dore GJ. 2013. Breaking down the barriers to hepatitis $\mathrm{C}$ virus (HCV) treatment among individuals with HCV/HIV coinfection: action required at the system, provider, and patient levels. J Infect Dis $\mathbf{2 0 7}$ (Suppl 1): S19-S25. doi:10.1093/infdis/jis928

Grebely J, Lamoury FMJ, Hajarizadeh B, Mowat Y, Marshall AD, Bajis S, Marks P, Amin J, Smith J, Edwards M, et al. 2017. Evaluation of the Xpert HCV Viral Load point-ofcare assay from venepuncture-collected and finger-stick capillary whole-blood samples: a cohort study. Lancet Gastroenterol Hepatol 2: 514-520. doi:10.1016/S24681253(17)30075-4

Gvinjilia L, Nasrullah M, Sergeenko D, Tsertsvadze T, Kamkamidze G, Butsashvili M, Gamkrelidze A, Imnadze P, Kvaratskhelia V, Chkhartishvili N, et al. 2016. National progress toward hepatitis C elimination-Georgia, 20152016. MMWR Morb Mortal Wkly Rep 65: 1132-1135. doi:10.15585/mmwr.mm654la2 
Hajarizadeh B, Grebely J, Martinello M, Matthews GV Lloyd AR, Dore GJ. 2016. Hepatitis C treatment as prevention: evidence, feasibility, and challenges. Lancet Gastroenterol Hepatol 1: 317-327. doi:10.1016/S2468-1253 (16)30075-9

Harris M, Rhodes T. 2013. Hepatitis C treatment access and uptake for people who inject drugs: a review mapping the role of social factors. Harm Reduct J 10: 7. doi:10.1186/ 1477-7517-10-7

Hecht R, Hiebert L, Spearman WC, Sonderup MW, Guthrie T, Hallett TB, Nayagam S, Razavi H, Soe-Lin S, VilakaziNhlapo K, et al. 2018. The investment case for hepatitis B and $\mathrm{C}$ in South Africa: adaptation and innovation in policy analysis for disease program scale-up. Health Policy Plan 33: 528-538. doi:10.1093/heapol/czy018

Heimbach JK, Kulik LM, Finn RS, Sirlin CB, Abecassis MM, Roberts LR, Zhu AX, Murad MH, Marrero JA. 2018. AASLD guidelines for the treatment of hepatocellular carcinoma. Hepatology 67: 358-380. doi:10.1002/hep .29086

Hellard M, Doyle JS, Sacks-Davis R, Thompson AJ, McBryde E. 2014. Eradication of hepatitis C infection: the importance of targeting people who inject drugs. Hepatology 59: 366-369. doi:10.1002/hep.26623

Hellard M, McBryde E, Sacks Davis R, Rolls DA, Higgs P, Aitken C, Thompson A, Doyle J, Pattison P, Robins G. 2015. Hepatitis $C$ transmission and treatment as prevention-the role of the injecting network. Int J Drug Policy 26: 958-962. doi:10.1016/j.drugpo.2015.05.006

Hermetet C, Dubois F, Gaudy-Graffin C, Bacq Y, Royer B, Gaborit C, D'Alteroche L, Desenclos JC, Roingeard P, Grammatico-Guillon L. 2017. Continuum of hepatitis C care in France: a 20-year cohort study. PLoS ONE 12: e0183232. doi:10.1371/journal.pone.0183232

Hoornenborg E, Achterbergh RCA, Schim van der Loeff MF, Davidovich U, Hogewoning A, de Vries HJC, Schinkel J, Prins M, van de Laar TJW; Amsterdam PrEp Project Team in the HIV Transmission Elimination AMsterdam Initiative, MOSAIC study group. 2017. MSM starting preexposure prophylaxis are at risk of hepatitis C virus infection. AIDS 31: 1603-1610. doi:10.1097/QAD .0000000000001522

Hopkins DR. 2013. Disease eradication. N Engl J Med 368: 54-63. doi:10.1056/NEJMra1200391

Hutchinson SJ, Roy KM, Wadd S, Bird SM, Taylor A, Anderson E, Shaw L, Codere G, Goldberg DJ. 2006. Hepatitis $\mathrm{C}$ virus infection in Scotland: epidemiological review and public health challenges. Scott Med J 51: 8-15. doi:10 .1258/RSMSMJ.51.2.8

Hutchinson SJ, Dillon JF, Fox R, McDonald SA, Innes HA, Weir A, McLeod A, Aspinall EJ, Palmateer NE, Taylor A, et al. 2015. Expansion of HCV treatment access to people who have injected drugs through effective translation of research into public health policy: Scotland's experience. Int J Drug Policy 26: 1041-1049. doi:10.1016/j.drugpo 2015.05.019

Iyengar S, Tay-Teo K, Vogler S, Beyer P, Wiktor S, de Joncheere K, Hill S. 2016. Prices, costs, and affordability of new medicines for hepatitis $C$ in 30 countries: an economic analysis. PLoS Med 13: e1002032. doi:10.1371/journal .pmed.1002032
Jin F, Matthews GV, Grulich AE. 2017. Sexual transmission of hepatitis $\mathrm{C}$ virus among gay and bisexual men: a systematic review. Sex Health 14: 28-41. doi:10.1071/ SH16141

Kandeel A, Genedy M, El-Refai S, Funk AL, Fontanet A, Talaat M. 2017. The prevalence of hepatitis $C$ virus infection in Egypt 2015: implications for future policy on prevention and treatment. Liver Int 37: 45-53. doi:10.1111/ liv.13186

The Kirby Institute. 2017. Monitoring hepatitis C treatment uptake in Australia (Issue 8). The Kirby Institute, UNSW Sydney, Sydney, NSW, Australia.

Kouyoumjian SP, Chemaitelly H, Abu-Raddad LJ. 2018. Characterizing hepatitis $\mathrm{C}$ virus epidemiology in Egypt: systematic reviews, meta-analyses, and meta-regressions. Sci Rep 8: 1661. doi:10.1038/s41598-017-17936-4

Kwon JA, Anderson J, Kerr CC, Thein HH, Zhang L, Iversen J, Dore GJ, Kaldor JM, Law MG, Maher L, et al. 2012 Estimating the cost-effectiveness of needle-syringe programs in Australia. AIDS 26: 2201-2210. doi:10.1097/ QAD.0b013e3283578b5d

Lambert SM, Page AN, Wittmann J, Hayllar JS, Ferndale CW, Bain TM, Macdonald GA. 2011. General practitioner attitudes to prescribing hepatitis $\mathrm{C}$ antiviral therapy in a community setting. Aust J Prim Health 17: 282-287. doi:10.1071/PY10069

Lawitz E, Poordad FF, Pang PS, Hyland RH, Ding X, Mo H, Symonds WT, McHutchison JG, Membreno FE. 2014 Sofosbuvir and ledipasvir fixed-dose combination with and without ribavirin in treatment-naive and previously treated patients with genotype 1 hepatitis $\mathrm{C}$ virus infection (LONESTAR): an open-label, randomised, phase 2 trial. Lancet 383: 515-523. doi:10.1016/S0140-6736(13) 62121-2

Lazarus JV, Wiktor S, Colombo M, Thursz M. 2017. Microelimination - a path to global elimination of hepatitis C. J Hepatol 67: 665-666. doi:10.1016/j.jhep.2017.06.033

Lazarus JV, Safreed-Harmon K, Thursz MR, Dillon JF, ElSayed MH, Elsharkawy AM, Hatzakis A, Jadoul M, Prestileo T, Razavi H, et al. 2018. The micro-elimination approach to eliminating hepatitis C: strategic and operational considerations. Semin Liver Dis 38: 181-192. doi:10 1055/s-0038-1666841

Lemoine M, Cooke GS. 2018. The Egyptian hepatitis C programme: a model of HCV treatment intervention? J Hepatol 68: 638-639. doi:10.1016/j.jhep.2018.01.021

Liakina V, Hamid S, Tanaka J, Olafsson S, Sharara AI, Alavian SM, Gheorghe L, El Hassan ES, Abaalkhail F, Abbas $Z$, et al. 2015. Historical epidemiology of hepatitis $C$ virus (HCV) in select countries-volume 3. J Viral Hepat 22 (Suppl 4): 4-20. doi:10.1111/jvh.12475

Maaroufi A, Vince A, Himatt SM, Mohamed R, Fung J, Opare-Sem O, Workneh A, Njouom R, Al Ghazzawi I, Abdulla M, et al. 2017. Historical epidemiology of hepatitis C virus in select countries-volume 4. J Viral Hepat 24(Suppl 2): 8-24. doi:10.1111/jvh.12762

Martin NK, Hickman M, Hutchinson SJ, Goldberg DJ, Vickerman P. 2013a. Combination interventions to prevent HCV transmission among people who inject drugs: modeling the impact of antiviral treatment, needle and syringe programs, and opiate substitution therapy. Clin Infect Dis 57(Suppl 2): S39-S45. doi:10.1093/cid/cit296 
M. Hellard et al.

Martin NK, Vickerman P, Grebely J, Hellard M, Hutchinson SJ, Lima VD, Foster GR, Dillon JF, Goldberg DJ, Dore GJ, et al. 2013b. Hepatitis C virus treatment for prevention among people who inject drugs: modeling treatment scale-up in the age of direct-acting antivirals. Hepatology 58: 1598-1609. doi:10.1002/hep.26431

Martin NK, Vickerman P, Dore GJ, Grebely J, Miners A, Cairns J, Foster GR, Hutchinson SJ, Goldberg DJ, Martin TCS, et al. 2016. Prioritization of HCV treatment in the direct-acting antiviral era: an economic evaluation. J Hepatol 65: 17-25. doi:10.1016/j.jhep.2016.02.007

McLeod A, Weir A, Aitken C, Gunson R, Templeton K, Molyneaux P, McIntyre P, McDonald S, Goldberg D, Hutchinson S. 2014. Rise in testing and diagnosis associated with Scotland's Action Plan on hepatitis C and introduction of dried blood spot testing. J Epidemiol Community Health 68: 1182-1188. doi:10.1136/jech-2014204451

Medicines Patent Pool. 2015. Available at medicinespatent pool.org/what-we-do/our-work/hepatitis-c

Mesquita F, Santos ME, Benzaken A, Corrêa RG, Cattapan E, Sereno LS, Moscoso Naveira MC. 2016. The Brazilian comprehensive response to hepatitis $\mathrm{C}$ : from strategic thinking to access to interferon-free therapy. BMC Public Health 16: 1-6. doi:10.1186/s12889-016-3784-4

Murphy K. 2018. Just 12 countries worldwide on track to eliminate hepatitis C infection by 2030, with United Kingdom, Italy and Spain among those joining the list. CDA Foundation, Lafayette, $\mathrm{CO}$.

Nasrullah M, Sergeenko D, Gamkrelidze A, Averhoff F. 2017a. HCV elimination-lessons learned from a small Eurasian country, Georgia. Nat Rev Gastroenterol Hepatol 14: 447-448. doi:10.1038/nrgastro.2017.100

Nasrullah M, Sergeenko D, Gvinjilia L, Gamkrelidze A, Tsertsvadze T, Butsashvili M, Metreveli D, Sharvadze L, Alkhazashvili M, Shadaker S, et al. 2017b. The role of screening and treatment in national progress toward hepatitis C elimination-Georgia, 2015-2016. MMWR Morb Mortal Wkly Rep 66: 773-776. doi:10.15585/mmwr .mm6629a2

Ni YH, Chang MH, Wu JF, Hsu HY, Chen HL, Chen DS. 2012. Minimization of hepatitis B infection by a 25 -year universal vaccination program. $J$ Hepatol 57: 730-735. doi:10.1016/j.jhep.2012.05.021

Olafsson S, Tyrfingsson T, Runarsdottir V, Bergmann OM, Hansdottir I, Björnsson ES, Johannsson B, Sigurdardottir B, Fridriksdottir RH, Löve A, et al. 2018. Treatment as prevention for hepatitis $\mathrm{C}$ (TraP Hep C) - a nationwide elimination programme in Iceland using direct-acting antiviral agents. J Intern Med 283: 500-507. doi:10 $.1111 /$ joim. 12740

Palmateer NE, Taylor A, Goldberg DJ, Munro A, Aitken C, Shepherd SJ, McAllister G, Gunson R, Hutchinson SJ. 2014. Rapid decline in HCV incidence among people who inject drugs associated with national scale-up in coverage of a combination of harm reduction interventions. PLOS ONE 9: e104515. doi:10.1371/journal.pone.0104515

Papatheodoridis GV, Hatzakis A, Cholongitas E, BaptistaLeite R, Baskozos I, Chhatwal J, Colombo M, Cortez-Pinto H, Craxi A, Goldberg D, et al. 2018. Hepatitis C: the beginning of the end-key elements for successful Europe- an and national strategies to eliminate HCV in Europe. $J$ Viral Hepat 25: 6-17. doi:10.1111/jvh.12875

Pedrana A, Howell J, Schroeder S, Scott N, Wilson D, Kuschel C, Aufegger L, Hellard M. 2018. Eliminating viral hepatitis: the investment case. World Innovation Summit for Health, Doha, Qatar.

Pfaender S, Brown RJ, Pietschmann T, Steinmann E. 2014. Natural reservoirs for homologs of hepatitis $C$ virus. Emerg Microbes Infect 3: 1-9. doi:10.1038/emi.2014.19

Platt L, Minozzi S, Reed J, Vickerman P, Hagan H, French C, Jordan A, Degenhardt L, Hope V, Hutchinson S, et al. 2017. Needle syringe programmes and opioid substitution therapy for preventing hepatitis $\mathrm{C}$ transmission in people who inject drugs. Cochrane Database Syst Rev 9: CD012021.

Platt L, Minozzi S, Reed J, Vickerman P, Hagan H, French C, Jordan A, Degenhardt L, Hope V, Hutchinson S, et al. 2018. Needle and syringe programmes and opioid substitution therapy for preventing HCV transmission among people who inject drugs: findings from a Cochrane review and meta-analysis. Addiction 113: 545-563. doi:10.1111/ add.14012

Poordad F, Lawitz E, Kowdley KV, Cohen DE, Podsadecki T, Siggelkow S, Heckaman M, Larsen L, Menon R, Koev G, et al. 2013. Exploratory study of oral combination antiviral therapy for hepatitis C. N Engl J Med 368: 45-53. doi:10.1056/NEJMoa1208809

Popping S, El-Sayed M, Feld J, Hatzakis A, Hellard M, Lesi O, Ninburg M, Ward J, Boucher C. 2018. Report from the International Viral Hepatitis Elimination Meeting (IVHEM), 17-18 November 2017, Amsterdam, The Netherlands: gaps and challenges in the WHO 2030 hepatitis C elimination framework. J Virus Erad 4: 193-195.

Rosenthal ES, Graham CS. 2016. Price and affordability of direct-acting antiviral regimens for hepatitis $\mathrm{C}$ virus in the United States. Infect Agents Cancer 11: 24. doi:10.1186/ s13027-016-0071-z

Saraswat V, Norris S, de Knegt RJ, Sanchez Avila JF, Sonderup M, Zuckerman E, Arkkila P, Stedman C, Acharya S, Aho I, et al. 2015. Historical epidemiology of hepatitis C virus (HCV) in select countries-volume 2. J Viral Hepat 22(Suppl 1): 6-25. doi:10.1111/jvh.12350

Scott N, Iser DM, Thompson AJ, Doyle JS, Hellard ME. 2016. Cost-effectiveness of treating chronic hepatitis C virus with direct-acting antivirals in people who inject drugs in Australia. J Gastroenterol Hepatol 31: 872-882. doi:10.1111/jgh.13223

Scott N, Doyle JS, Wilson DP, Wade A, Howell J, Pedrana A, Thompson A, Hellard ME. 2017a. Reaching hepatitis C virus elimination targets requires health system interventions to enhance the care cascade. Int J Drug Policy 47: 107-116. doi:10.1016/j.drugpo.2017.07.006

Scott N, McBryde ES, Thompson A, Doyle JS, Hellard ME. 2017b. Treatment scale-up to achieve global HCV incidence and mortality elimination targets: a cost-effectiveness model. Gut 66: 1507-1515. doi:10.1136/gutjnl-2016311504

Scott N, Ólafsson S, Gottfreðthsson M, Tyrfingsson T, Rúnarsdóttir V, Hansdottir I, Hernandez UB, Sigmundsdóttir G, Hellard M. 2018a. Modelling the elimination of hepatitis $\mathrm{C}$ as a public health threat in Iceland: a goal 
attainable by 2020. J Hepatol 68: 932-939. doi:10.1016/j .jhep.2017.12.013

Scott N, Sacks-Davis R, Pedrana A, Doyle J, Thompson A Hellard M. 2018b. Eliminating hepatitis C: the importance of frequent testing of people who inject drugs in high-prevalence settings. J Viral Hepat 25: 1472-1480. doi:10.1111/jvh.12975

Stanaway JD, Flaxman AD, Naghavi M, Fitzmaurice C, Vos T, Abubakar I, Abu-Raddad LJ, Assadi R, Bhala N, Cowie B. 2016. The global burden of viral hepatitis from 1990 to 2013: findings from the Global Burden of Disease Study 2013. Lancet 388: 1081-1088. doi:10.1016/S0140-6736 (16)30579-7

Strickland GT. 2006. Liver disease in Egypt: hepatitis C superseded schistosomiasis as a result of iatrogenic and biological factors. Hepatology 43: 915-922. doi:10.1002/hep .21173

The Boston Consulting Group. 2017. Road to elimination: barriers and best practices in hepatitis $\mathrm{C}$ management: overview of the status of HCV care in Europe and Australia. Boston, MA.

The World Bank. 2017. Eliminating hepatitis C from Egypt: 2017 update on current trends and policy recommendations. In Egypt's Viral Hepatitis Program, pp. 1-23. The World Bank, Washington, DC.

Turner KM, Hutchinson S, Vickerman P, Hope V, Craine N, Palmateer N, May M, Taylor A, De Angelis D, Cameron S, et al. 2011. The impact of needle and syringe provision and opiate substitution therapy on the incidence of hepatitis $C$ virus in injecting drug users: pooling of UK evidence. Addiction 106: 1978-1988. doi:10.1111/j.13600443.2011.03515.x

Umar M, Bilal M. 2012. Hepatitis C, a mega menace: a Pakistani perspective. J Pakistan Medical Students 2: 68-72.

United Nations. 2015. Transforming our world: the 2030 agenda for sustainable development. UN Publishing, New York.

Viral Hepatitis Prevention Board. 2016. Innovative financing into hepatitis $B$ and $C$ prevention and treatment in low and middle income countries. IFPMA, Geneva.

Wade AJ, Macdonald DM, Doyle JS, Gordon A, Roberts SK, Thompson AJ, Hellard ME. 2015. The cascade of care for an Australian community-based hepatitis $\mathrm{C}$ treatment service. PLOS ONE 10: e0142770. doi:10.1371/journal .pone. 0142770

Ward T, Gordon J, Jones B, Bennett H, Webster S, Kalsekar A, Yuan Y, Brenner M, McEwan P. 2017. Value of sustained virologic response in patients with hepatitis $\mathrm{C}$ as a function of time to progression of end-stage liver disease. Clin Drug Investig 37: 61-70. doi:10.1007/s40261-0160458-z

World Health Assembly. 2014. Resolution WHA67.6. Hepatitis. In Sixty-Seventh World Health Assembly. WHO, Geneva, May 19-24.

World Health Organization. 2016a. Combating hepatitis B and $C$ to reach elimination by 2030. WHO, Geneva.

World Health Organization. 2016b. Global health sector strategy on viral hepatitis 2016-2021: towards ending viral hepatitis. WHO, Geneva.
World Health Organization. 2016c. Global report on access to hepatitis $C$ treatment. Focus on overcoming barriers. WHO, Geneva.

World Health Organization. 2017a. Global hepatitis report 2017. WHO, Geneva. www.who.int/hepatitis/ publications/global-hepatitis-report2017/en

World Health Organization. 2017b. WHO guidelines on hepatitis B and C testing. WHO, Geneva. www.who.int/ hepatitis/publications/guidelines-hepatitis-c-b-testing/en

World Health Organization. 2018a. Guidelines for the care and treatment of persons diagnosed with chronic hepatitis $C$ virus infection. WHO, Geneva.

World Health Organization. 2018b. Hepatitis C fact sheet. WHO, Geneva.

World Health Organization Regional Office for Africa. 2017. Prevention, care and treatment of viral hepatitis in the African region: framework for action, 2016-2020. WHO Africa, Republic of Congo.

World Hepatitis Alliance. 2018. Find the missing millions. London, www.worldhepatitisalliance.org/find-missingmillions.

World Innovation Summit for Health. 2018. Research forum on viral hepatitis. WISH, Doha, Qatar.

Wylie L, Hutchinson S, Liddell D, Rowan N. 2014. The successful implementation of Scotland's hepatitis C action plan: what can other European stakeholders learn from the experience? a Scottish voluntary sector perspective. BMC Infect Dis 14: S7. doi:10.1186/1471-2334-14S6-S7

Yehia BR, Schranz AJ, Umscheid CA, Re VL 3rd. 2014. The treatment cascade for chronic hepatitis $\mathrm{C}$ virus infection in the United States: a systematic review and meta-analysis. PLOS ONE 9: e101554. doi:10.1371/journal.pone .0101554

YouGov. 2018. International views on healthcare, online survey. World Innovation Summit for Health, Doha, Qatar.

Younossi Z, Stepanova M, Omata M, Mizokami M, Walters M, Hunt S. 2017a. Health utilities using SF-6D scores in Japanese patients with chronic hepatitis $\mathrm{C}$ treated with sofosbuvir-based regimens in clinical trials. Health Qual Life Outcomes 15: 25. doi:10.1186/s12955-0170598-8

Younossi ZM, Stepanova M, Henry L, Han KH, Ahn SH, Lim YS, Chuang WL, Kao JH, Kinh N, Lai CL, et al. 2017b. The effect of interferon-free regimens on healthrelated quality of life in East Asian patients with chronic hepatitis C. Liver Int 38: 1179-1187. doi:10.1111/liv .13650

Younossi ZM, Stepanova M, Janssen HLA, Agarwal K, Nguyen MH, Gane E, Tsai N, Younossi I, Racila A. 2018a. Effects of treatment of chronic hepatitis B virus infection on patient-reported outcomes. Clin Gastroenterol Hepatol 16: 1641-1649.e6. doi:10.1016/j.cgh.2018 .09 .041

Younossi ZM, Tanaka A, Eguchi Y, Henry L, Beckerman R, Mizokami M. 2018b. Treatment of hepatitis C virus leads to economic gains related to reduction in cases of hepatocellular carcinoma and decompensated cirrhosis in Japan. J Viral Hepat 25: 945-951. doi:10.1111/jvh .12886 
M. Hellard et al.

Zhou K, Fitzpatrick T, Walsh N, Kim JY, Chou R, Lackey M, Scott J, Lo YR, Tucker JD. 2016. Interventions to optimise the care continuum for chronic viral hepatitis: a systematic review and meta-analyses. Lancet In fect Dis 16: 1409-1422. doi:10.1016/S1473-3099(16) 30208-0
Zhuang G, Zhang M, Liu Y, Guo Y, Wu Q, Zhou K, Ji Z, Zhang X. 2014. Significant impairment of health-related quality of life in mainland Chinese patients with chronic hepatitis B: a cross-sectional survey with pair-matched healthy controls. Health Qual Life Outcomes 12: 101. doi:10.1186/1477-7525-12-101 


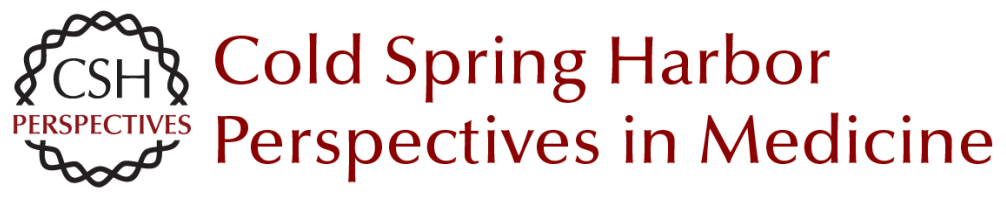

\section{The Elimination of Hepatitis $\mathbf{C}$ as a Public Health Threat}

Margaret Hellard, Sophia E. Schroeder, Alisa Pedrana, Joseph Doyle and Campbell Aitken

Cold Spring Harb Perspect Med 2020; doi: 10.1101/cshperspect.a036939 originally published online November 11, 2019

Subject Collection Hepatitis C Virus: The Story of a Scientific and Therapeutic Revolution

Antibody Responses in Hepatitis C Infection Mansun Law

T-Cell Immunity against the Hepatitis C Virus: A Persistent Research Priority in an Era of Highly Effective Therapy

Stephanie Smith, Jonathan R. Honegger and Christopher Walker

Interferon-Free Hepatitis C Virus Therapy Jean-Michel Pawlotsky

Animal Models of Hepatitis C Virus Infection Alexander Ploss and Amit Kapoor

Natural History of Hepatic and Extrahepatic Hepatitis C Virus Diseases and Impact of Interferon-Free HCV Therapy

Francesco Negro

Hepatitis C Virus Epidemiology and the Impact of Interferon-Free Hepatitis C Virus Therapy Jeffrey V. Lazarus, Elena Roel and Ahmed M. Elsharkawy

Hepatitis C Virus Entry: Protein Interactions and Fusion Determinants Governing Productive Hepatocyte Invasion

Gisa Gerold, Rebecca Moeller and Thomas Pietschmann

Hepatitis C Virus Structure: Defined by What It Is Not

Altaira D. Dearborn and Joseph Marcotrigiano
Innate Immunity in Hepatitis C Virus Infection Johannes Schwerk, Amina Negash, Ram Savan, et al.

HCV Assembly and Egress via Modifications in Host Lipid Metabolic Systems Kunitada Shimotohno

Control of HCV Infection by Natural Killer Cells and Macrophages

Hugo R. Rosen and Lucy Golden-Mason

The Elimination of Hepatitis $\mathbf{C}$ as a Public Health

Threat Margaret Hellard, Sophia E. Schroeder, Alisa Pedrana, et al.

Hepatitis C Virus Replication Keisuke Tabata, Christopher J. Neufeldt and Ralf Bartenschlager

Challenges and Promise of a Hepatitis C Virus Vaccine Andrea L. Cox

Rewiring Host Signaling: Hepatitis C Virus in Liver Pathogenesis

Alessia Virzì, Armando Andres Roca Suarez, Thomas F. Baumert, et al.

Hepatitis C Virus: $\mathbf{3 0}$ Years after Its Discovery Michael Houghton

For additional articles in this collection, see http://perspectivesinmedicine.cshlp.org/cgi/collection/ 